https://doi.org/10.48009/2_iis_2007_166-170

\title{
STRATEGIC IMPLEMENTATION OF ORGANIZATIONAL LEARNING: AN EMPIRICAL STUDY
}

\author{
Zong Dai, Alfred University, daiz@alfred.edu \\ Frank Duserick, Alfred University, fduserick@alfred.edu \\ Wilfred V. Huang, Alfred University, fhuang@alfred.edu
}

\begin{abstract}
This paper is a case study of creating learning-based competitive advantage through organizational learning. It examines how two business firms create competitiveness through transforming themselves into learning organizations. Data was collected and analyzed at corporate level of the subject organizations. A conceptual model of creating learning-based competitive advantage through organizational learning has been developed based on the findings.
\end{abstract}

Keywords: Learning-based competitive advantage, Organizational learning, return on learning, knowledge, skills, performance

\section{INTRODUCTION}

In quest of competitive advantage, resource-based theory (RBT) has suggested that competitive advantage is derived from a bundle of strategic resources and focused on individual resources while under-exploring multiple resources interactions [e.g., 4, 9, 13, 15]. Organizational economists have begun viewing organizational learning (OL) as a strategic resource [e.g., 7, 15]. Fiol and Lyles [11] suggest that OL includes changes in both of cognition and behavior dimensions. Importantly OL presumes benefits from interactions between resources and their use [15].

However, the literature fails to capture competitive advantages derived from dynamic OL [15]. Particularly, it lacks empirical studies in how the firm reconfigures and operates its resource base for competitive advantage under the new conditions through OL $[11,15]$.

Yin [18] and Schwandt [14] have suggested that the case study method is deemed proper for a research project that is exploratory in nature.

This paper is a case study to examine how the firm creates competitive advantage through organizational learning.
Two business firms-Dow Chemical Company and Caterpillar Inc were selected from the 2004-2006 ASTD's ${ }^{1}$ BEST Awards winners of organizational learning and performance in five countries. Data collection has been conducted through the companies' websites, interview and documentation such as annual reports, archival records, financial reports, electronic databases, and other publications. Interviews were conducted with focused topics. Interviewees include Sonya Davis and Don Gaertner, both are senior human resource development specialists at Dow. The author also consults the internal presentations by the president of Caterpillar University.

\section{CATERPILLAR UNIVERSITY}

Caterpillar is the world's leading manufacturer of construction and mining equipment, diesel and natural gas engines, industrial gas turbines and a wide and growing offering of related services, with 2006 sales and revenues of $\$ 41.517$ billion [5]. Caterpillar serves industries from construction, transportation, mining, forestry, energy, logistics, electronics, Financing and electronic power generation. Its products are sold in nearly 200 countries. The company's worldwide employment was 93233 in third quarter 2006, with 277 facilities around the world $[5,17]$.

In the early 1990s, in order to implement a customercentered strategy, the company moved toward a decentralized corporate structure. The company was

1 ASTD (American Society for Training \& Development) is the world's largest association dedicated to workplace learning and performance professionals. ASTD's 70,000 members and associates come from more than 100 countries and thousands of organizations--multinational corporations, medium-sized and small businesses, government, academia, consulting firms, and product and service suppliers [2]. 
divided into 30 business units that were specific in focus. While the business units became increasingly autonomous, the company suffered a lack of enterprise's leadership, standards, consistency and efficiency. It was under this context that a centralized enterprise learning and development initiativeCaterpillar University was established in 2001.

Caterpillar University's mission is to improve human resource performance and initiate a renewal of organizational synergy that was lost due to the decentralization. The teaching content is determined by the colleges, with input from advisory boards and learning managers in the business units. The university started its learning initiatives with an elearning library of soft-skill course. As the university has evolved, it has developed more learning requirements and programs outsourced from elearning vendors such as Harvard Business School Publishing's online resources. The following figures highlight Caterpillar University's learning strategy, implementation, performance measurement and results.

Figure 1: Caterpillar University: Strategy, Implementation and Performance

\begin{tabular}{|c|c|c|}
\hline Strategic Learning & Learning at Caterpillar & Return on Learning (ROL) \\
\hline $\begin{array}{l}\text { Learning is linked to } \\
\text { business unit goals and } \\
\text { critical success factors } \\
\text { Focus is on highest-priority } \\
\text { learning } \\
\$ 100 \text { million spent on } \\
\text { learning is on the right } \\
\text { learning } \\
\text { Accomplished informally in } \\
\text { the first two years } \\
\text { Formalized with Division } \\
\text { (business unit) Learning } \\
\text { Plans and Enterprise } \\
\text { Learning Plan }\end{array}$ & $\begin{array}{ll} & \text { Knowledge Sharing } \\
- & \text { E-learning } \\
- & \text { Leadership development } \\
& \text { (coaching, workshops, } \\
& \text { facilitation) } \\
-\quad \text { Classroom training } \\
-\quad \text { Competencies } \\
-\quad \text { Career development } \\
\text { - } \quad \text { Change management } \\
\text { Systems support, such as } \\
\text { Learning Management } \\
\text { System and Knowledge } \\
\text { Network }\end{array}$ & $\begin{array}{l}\text { Understand the costs and the benefits } \\
\text { Ensure benefits are greater than costs } \\
\text { Ensure ROL \% exceeds corporate hurdle rate } \\
\text { and compares favorably with other investments } \\
\text { Learn how to reduce costs and increase benefits } \\
\text { Focus process owners and leaders on } \\
\text { importance of participation and application } \\
\text { Manage the deployment for success - achieve } \\
\text { the targeted ROL } \\
\text { Three stage approach to ROI: } 1 \text {. Estimate ROI } \\
\text { at development, 2. Forecast after pilot, 3. } \\
\text { Complete ROI at close } \\
\text { Learn, modify, improve }\end{array}$ \\
\hline
\end{tabular}

Figure 2: Caterpillar University: Return on Learning

\begin{tabular}{|l|c|c|c|c|}
\hline \multicolumn{5}{|c|}{ Return on Learning - Improvements in Performance } \\
\hline \multicolumn{1}{|c|}{ Primary CSFs } & $\begin{array}{c}\text { Participants } \\
\mathbf{2 0 0 4}\end{array}$ & Net Benefits (mil) & Participants 2005 & Net Benefits (mil) \\
\hline People, growth, cost & 9,845 & $\$ 31.9$ & 5,000 & $\$ 16.2$ \\
\hline All & 35,666 & $\$ 9.0$ & 35,000 & $\$ 9.1$ \\
\hline Growth, people & 2,500 & $\$ 7.8$ & 2,700 & $\$ 6.4$ \\
\hline People, growth & 850 & $\$ 3.9$ & 2,000 & $\$ 12.7$ \\
\hline People, growth & & & 500 & $\$ 1.3$ \\
\hline People, growth, cost & 385 & & 3,000 & $\$ 2.8$ \\
\hline Growth, cost, people & 8,187 & $\$ .5$ & 1,000 & $\$ 1.3$ \\
\hline People, cost & 850 & $\$ 9.9$ & 1,100 & $\$ 19.5$ \\
\hline Cost, people, growth & 150 & $\$ .4$ & 500 & $\$ .5$ \\
\hline Growth, cost, people & 58,433 & $\$ 2.0$ & 73,800 & $\$ 6.5$ \\
\hline \multicolumn{2}{|l|}{} & $\$ 65.4$ & & $\$ 76.3$ \\
\hline Source: Adapted from Vance [16]. & & & \\
\hline
\end{tabular}

\section{DOW'S LEARNING INTITIATIVE}

Dow Chemical Company is a diversified chemical company that offers a broad range of products and services to customers in more than 175 countries, from fresh water, food and pharmaceuticals to paints, packaging and personal care products. Dow has annual sales of $\$ 46$ billion and employs 42,000 people worldwide [10].

Since 1995, Dow has begun shifting to global expansion and then the organizational structure has 
been based on business units around the world. A new challenge the company has faced is how to provide the latest and cost effective learning just in time to its learners where and when they want it. In 2001, Dow developed a comprehensive "people strategy" with continuous learning as a key element. Each business function is responsible for skill and knowledge development and examines people development and performance when developing its business plan. The functional learning leaders ensure that learning resources, curricula and technology are meeting the requirements of the business functions to improve employees and organizational goals and capabilities.

Each employee has goals aligned with the business plan and learning is an important part of employee goals and performance reviews. A significant measure of business scorecards is employee alignment (I know what to do), enablement (I know how to do it), and motivation (I want to do it) [1].

A technology solution for Dow's learning is the implementation of a global web-based learning management and delivery system (learn@dow.now). Courses are developed internally, purchased from external sources and/or developed specifically for Dow (five preferred vendors). The system provides "just-in-time" training to all employees globally and maintains the employee training records. Employees are in control and can receive training anytime and anywhere. 153,392 and 315,265 courses were completed respectively in 2000 and 2001. Today, 1,500 courses are available with subject areas range from safety to marketing. The future learning initiatives include video enhancements, NetMeeting/LearnLinc and using “learn@dow.now” to train customers, suppliers and distributors.

The following is the breakdown of cost and benefits for Dow's learning initiative, based on Davis' [8] presentation and the author's interviews in 2006 with Davis and Gaertner at Dow. In addition to savings in money, there are great reductions of administration time.

Figure 3: Cost/Savings for Dow's Learning Initiative

\begin{tabular}{|c|c|}
\hline Cost & Savings \\
\hline $\begin{array}{l}\text { Start-up Investment: } \\
\text { \$1 million to purchase project } \\
\text { Design team comprised of six employees and } \\
\text { managers } \\
\text { Ongoing cost: } \\
\text { Annual operational cost } \$ 540,000 \\
\text { One full-time manager } \\
\text { Five employees in part-time roles (functional } \\
\text { administrators), and learning coordinators. }\end{array}$ & $\begin{array}{l}\text { Savings in } 2000=\$ 22 \text { million } \\
\text { Savings in } 2001=\$ 45 \text { million } \\
\text { Projection for } 2002-2006=\$ 30 \text { million for each } \\
\text { year } \\
\text { Based on measurement of: } \\
\text { - Automatic vs. manual records } \\
\text { 口 Reduction of delivery and material cost } \\
\text { - Reduction in learner time }\end{array}$ \\
\hline
\end{tabular}

\section{DISCUSSION}

The two cases exemplify that in order to successfully compete in an increasingly changing business and technological environments, a firm can be successful in managing change through organizational learning.
A model of strategic learning evolution is developed to conceptualize the firms' approach to a strategic organizational learning. 
Figure 4: Strategic Learning Evolution

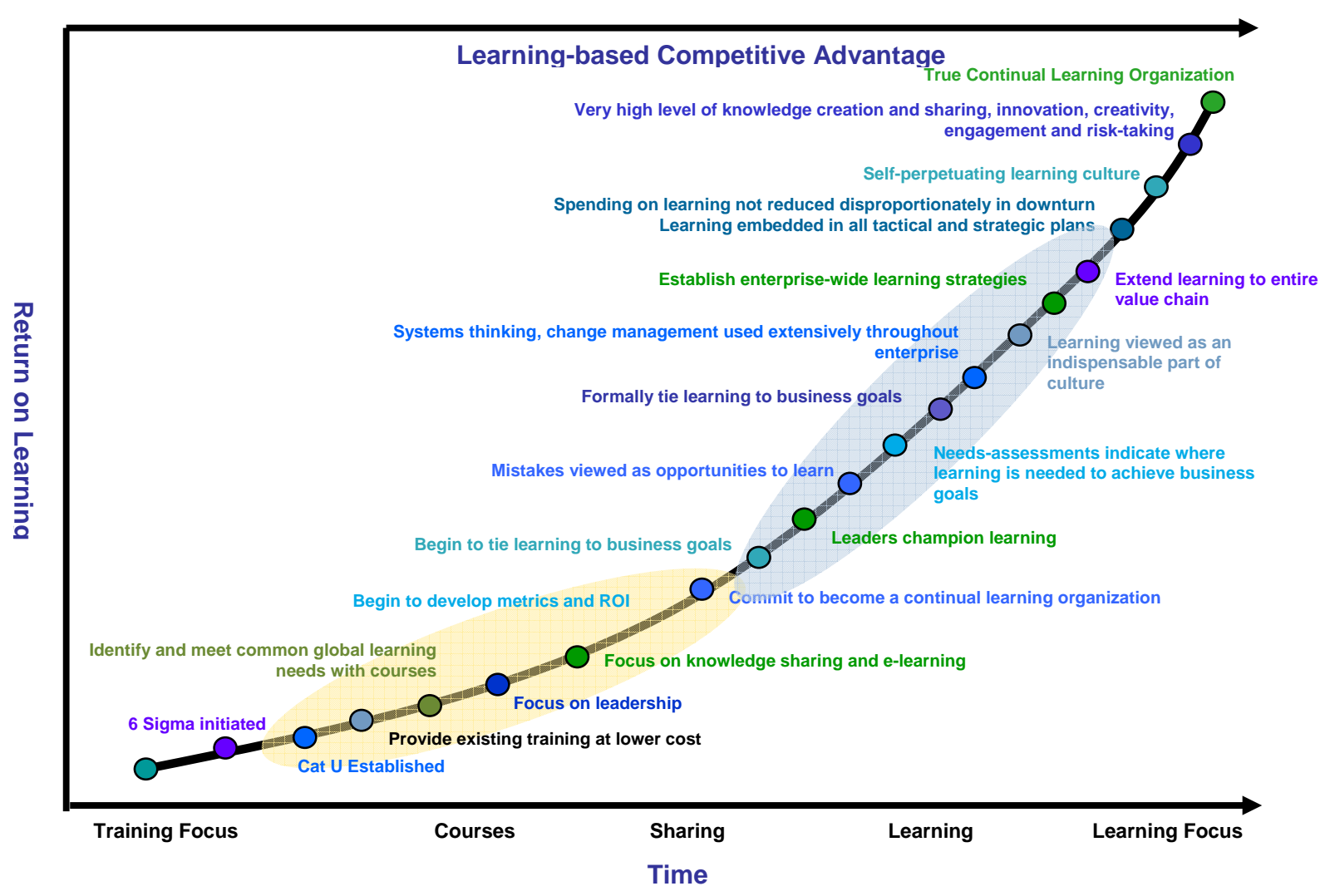

Note: This figure is adapted from Vance [16].

This model has three dimensions with the trajectory Caterpillar learning evolution filled in the model to visualize the concept. The first dimension is learning evolution along with the time line, exemplified by the Caterpillar learning as from training focus to strategic learning focus.

The second dimension is return on learning as described in both cases. Enlightened by the resourcebased view of firm and illustrated in the cases, the third dimension is the evolving learning-based competitive advantage represented by human resource upgrading and evolving.

If a firm successfully negotiated the learning evolution, it should obtain benefits from return on learning and learning-based competitive advantage. As described in the cases, the organizational learning platform interacts with different corporate resources and evolves from the unique combination of the firm's business strategy, competitive forces, corporate history and culture, and technological complexity. Thus, the competitive organizational learning is not easily imitated by competitors and the learning-based competitive advantage would be likely sustainable.

This conceptual model would serve as a blueprint for creating learning-based sustainable competitive advantage.

A business repositioning and/or organizational transformation through learning would be much less painful than an ordinary organizational changing process because of no resistance to change, and would be more likely successful. What the two cases have ultimately enlightened is what Hame and Heene [12] abstractly addressed; that is that the process of renewal rather than the source itself is considered to be the ultimate source of competitive advantage. Specifically, as demonstrated by the two firms, the process of how knowledge to be created and learned rather than knowledge itself is evidenced to be the source of competitive advantage. A strong learning capability like a wellspring injects fresh competence flow into the pool of corporate competence. 


\section{REFERENCES}

1. ASTD (2004). The Top, Retrieved January 25, 2006 from http://www.astd.org.

2. ASTD (2006). About ASTD. Retrieved January 25, 2006 from: http://www.astd.org/ASTD/About_ASTD.

3. ASTD (2006). The Next Level, Retrieved December 20, 2006 from http://www.astd.org.

4. Barney, J. B. (1991). Firm resources and sustained competitive advantage. Journal of Management, Vol. 17, No. 1, pp. 99-120.

5. Caterpillar (2007), Corporate Overview, http://www.cat.com/cda/layout?x=7.

6. Caterpillar (2001-2006). Annual Reports.

7. Cohen, W. M. \& Levinthal, D. A. (1989). Innovation and learning: the two faces of R\&D. Administrative Science Quarterly, Vol. 35, No. 1. pp. 128-152.

8. Davis, S. (2005). E-learning at Dow chemical. Retrieved at: http://www.learnshare.com/Seminars/Presentati ons/020801_webinar/020801_sonyadavis.ppt

9. Dierickx, I. and Cool, K. (1989). Asset stock accumulation and sustainability of competitive advantage. Management Science, Vol. 35, No. 12, pp. 1504-1511.

10. Dow Chemical Company (2006). http://www.dow.com/about/aboutdow/about.ht $\mathrm{m}$.
11. Fiol, C.M. and Lyles, M.A. (1995). Organizational learning. Academy of Management Review, Vol. 10 No. 4, pp. 803813.

12. Hamel, G. and Heene, A. (1994). Competencebased competition. Eds, Wiley, New York, NY.

13. Peteraf, M. A. (1993). The cornerstones of competitive advantage: a resource-based view. Strategic Management Journal, Vol. 14, No. 3, pp. 179-191.

14. Schwandt, T.A. (1997). Qualitative Inquiry. Thousand Oaks, CA: Sage.

15. Smith, K. A., Vasudevan, S. P., and Tanniru, M. R. (1996). Organizational learning and resourcebased theory: An intergrative model. Journal of Organizational Change Management, Bradford: Vol. 9, Iss. 6; pp. 41-57.

16. Vance, D. (2005). Best Practices in Corporate University Alignment, Governance, Evaluation and Metrics, An unpublished presentation at CCASTD Luncheon, Chicago, Illinois, July 8.

17. Vance, D. (2006). Best Practices in Governance, Alignment, Strategy, Metrics and Evaluation, ASTD International Conference and Exposition, May, Dallas, Texas.

18. Yin, R.K. (1994) Case Study Research: Design and Method, Sage Publications, London. 